УДК $343.16+343.37$

DOI https://doi.org/10.32849/2663-5313/2020.7.63

Андрій Саковсъкий, канд. юрид. наук, дочент, директор

Навчально-наукового інституту № 2

Національної академї внутрішніх справ

\title{
ОПЕРАТИВНО-РОЗШУКОВЕ ДОКУМЕНТУВАННЯ ЯК ПОШУКОВО-ПІЗНАВАЛЬНИЙ ПРОЦЕС І СКЛАДНИК ОПЕРАТИВНО-РОЗШУКОВОЇ ДІЯЛЬНОСТІ
}

Метою статті є надати визначення поняттю та охарактеризувати сутність оперативнорозшукового документування в оперативно-розшуковій діяльності, а також окреслити проблемні питання щодо його здійснення. У процесі дослідження використано наукові методи аналізу, індукцї та дедукиї.

Теоретичним підгрунтям иієї публікацї стали праці вітчизняних та іноземних вчених, присвячені аспектам діяльності органів досудового розслідування та підрозділів кримінальної поліщї, а також розгляду нормативно-правових актів, які регулюють їхню діяльність. Наукова новизна публікації полягає в системному аналізі сутності оперативно-розшукового документування. Надано авторсъке визначення «оперативно-розшукового документування».

Встановлено, що документування містить чимало смислових навантажень, які поєднуються в узгодженій діяльності, спрямованій на досягнення мети, виконання завдань або досягнення результату. Встановлено, що документування оперативними підрозділами має юридичні, організаиійі і тактичні особливості залежно від стадій (етапів), на яких воно проводиться, засобів, які при цьому використовуються, та форм, у яких воно втілюється.

В контексті окресленого виокремлені певні його етапи, які відрізняються завданнями, правовідносинами, формою. Зроблено висновок, що документування злочинів полягає у створенні та (або) одержанні документів, які містять фактичні дані про кримінально-карані діяння окремих осіб та груп. Суб'єктами документування злочинів можуть бути оперативні підрозділи, слідчий, прокурор. Воно здійснюється як в межах оперативно-розиукової діяльності, так і в межах кримінального процесу.

Документування злочинів є основним засобом одержання доказів-документів у кримінальному провадженні. Оперативне документування (документування, що здійснюється оперативними підрозділами) - діяльність оперативних підрозділів зі створення та (або) одержання документів, які містять інформачію, що може бути використана для прийняття рішень в оперативно-розшуковій діяльності, прийняття прочесуальних, організачійних і тактичних рішень та доказування у кримінальному провадженні.

Оперативно-розшукове документування - різновид оперативного документування, що здійснюється винятково в межах оперативно-розшукової діяльності. Оперативно-технічне документування - різновид оперативного документування, заснований на застосуванні технічних засобів одержання інформаиї̈, який не може бути проведений без їх використання.

Ключові слова: оперативно-розшукова діяльність, документування, оперативно-розшукове документування, документування вчинення злочину, кримінальна поліція.

Постановкапроблеми. Нині терміни «оперативне документування», «оперативно-розшукове документування», «документування злочинів» тощо широко використовуються в теорії та практиці оперативно-розшукової діяльності. За допомогою цих термінів розробники нормативно-правових актів Служби безпеки (далі - СБ) та Міністерства внутрішніх справ (далі - МВС) України конструюють визначальні для діяльності оперативних підрозділів норми права, а вчені формулюють основні положення власних наукових досліджень. Здебільшого науковці та практики не вдаються до аналізу відповідних понять, уникають визначення співвідношення та чіткого розмежування різних термінів, до складу яких включають документування.

Активне використання різних похідних від терміну «документування» дає підстави припустити, що без їх вживання розробники зазначених вище інструкцій не можуть унормувати відповідний сегмент діяльності 
оперативних підрозділів. Крім того, окремим оперативним підрозділам СБ України, Державної прикордонної служби України та податкової міліції у відомчих актах надано назву «підрозділи оперативного документування». Таким чином, унормовано, що оперативне документування є основним видом діяльності та головною функцією цих підрозділів.

Це знайшло своє закріплення й на законодавчому рівні. Так, у ст. 5 Закону України «Про оперативно-розшукову діяльність» [1] в числі інших підрозділів, уповноважених на проведення оперативно-розшукової діяльності (далі - ОРД), вказано на підрозділи оперативного документування СБ України та Державної прикордонної служби України.

Метою статті є визначення поняття та сутності оперативно-розшукового документування як пошуково-пізнавального процесу та складника оперативно-розшукової діяльності, а також окреслення проблемних питань щодо його здійснення.

Виклад основного матеріалу. Широкого вжитку термін «документування» та похідні від нього знайшли і в наукових дослідженнях з оперативно-розшукової діяльності. Вчені активно послуговуються ним для позначення процесу фіксації фактичних даних про різні види кримінальних правопорушень. Це стосується, зокрема, злочинів у сфері інтелектуальної власності, авторських та суміжних прав [2; 3], банківського кредитування [4], незаконного обігу наркотичних засобів [5]; проведення оперативного пошуку підрозділами карного розшуку [6].

Зазначені терміни в минулому здебільшого застосовувалися саме в теорії тапрактиці оперативно-розшукової діяльності. Серед вчених-криміналістів і представників науки кримінального процесу було більш прийнятим вести мову про «фіксацію фактичних даних», «збирання доказів» тощо. Лише окремі відомі криміналісти (Р.С. Белкін, В.К. Лисиченко, М.В. Салтевський, В.Г. Гончаренко та інші) цілком виправдано послуговувалися терміном «документування» та похідними від нього. Спостерігався і зворотній зв'язок. Так, М.А. Погорецький розглядав теорію доказів як методологічну основу оперативно-розшукового документування організованої злочинної діяльності [7].

У зв'язку 3 тенденцією зближення та взаємного проникнення ОРД та кримінального процесу, що була започаткована у 2012 році з прийняттям Кримінального процесуального кодексу України, спостерігається активне використання цього терміну у кримінальному процесі [8]
Окремі науковці, досліджуючи питання проведення негласних слідчих (розшукових) дій (далі - НСРД), пропонують доповнити цей інститут нормами, назви яких містять термін «документування». Так, В.Г. Уваров пропонує внести зміни до гл. 21 КПК України та запровадити статтю «Безпосередне спостереження та технічне документування юридично значущих фактів», до змісту якої зараховувати всі НСРД, передбачені ст. 260, 269 та 279 КПК України [9]. Якщо змістовне наповнення запропонованої норми є дискусійним, то їі назва відбиває процеси, що мають місце при проведенні НСРД, передбачені вказаними статтями [10].

Водночас термін «документування» та похідні від нього не знайшли належного використання законодавцем у правотворчому процесі. Так, поза межами ст. 5 термін «документування» зустрічається в Законі України «Про оперативно-розшукову діяльність» лише один раз - у п. 2 ч. 1 ст. 8 , де передбачено право оперативних підрозділів проводити контрольовану поставку та контрольовану і оперативну закупку товарів, предметів і речовин, у тому числі заборонених для обігу, у фізичних та юридичних осіб незалежно від форми власності з метою виявлення та документування фактів протиправних діянь [1]. При цьому законодавець зазначає, що проведення контрольованої поставки, контрольованої та оперативної закупок здійснюються згідно з положеннями ст. 271 Кримінального процесуального кодексу України.

Зазначена стаття не містить терміну «документування» та похідних від нього. Немає його ні у гл. 20 «Слідчі (розшукові) дії», ні у гл. 21 «Негласні слідчі (розшукові) дії». Він зустрічається лише у гл. 42 КПК України «Загальні засади міжнародного співробітництва». Так, ст. 569 «Контрольована поставка» передбачає, що слідчий органу досудового розслідування України в разі виявлення ним контрабандної поставки при проведенні процесуальних дій, у тому числі за запитом про міжнародну правову допомогу, має право не вилучати iї 3 місця закладки або транспортування, а за домовленістю з компетентними органами держави, куди їі адресовано, безперешкодно пропустити її через митний кордон України з метою виявлення, викриття та документування злочинної діяльності міжнародних злочинних організацій.

Частина 2 ст. 570 «Прикордонне переслідування» передбачає, що матеріали кримінального провадження щодо документування незаконної діяльності особи, яка вчинила незаконне переміщення через дер- 
жавний кордон України на території України, згідно з міжнародними договорами про прикордонне переслідування передаються відповідним органам держави, де цю особу притягнуто до кримінальної відповідальності, а в разі одержання таких матеріалів від відповідних органів іншої держави, вони долучаються до матеріалів досудового розслідування.

Таким чином, спостерігаються неоднакові підходи до використання терміну «документування»: науковці та розробники відомчих нормативно-правових актів цілком обгрунтовано ним послуговуються, а застосування його законодавцем є досить обмеженим та, цілком імовірно, випадковим.

У науці відсутні єдині погляди на сутність ключових понять, пов'язаних із документуванням, а вчені та представники відомчої правотворчості, часто без надання відповідних дефініцій, вживають різні похідні від нього («документування», «документування злочинів», «оперативне документування», «оперативно-розшукове документування», «документування оперативними підрозділами»).

Викладене зумовлює необхідність сформувати категоріально-понятійний апарат документування оперативними підрозділами. На мою думку, цілком логічно розглядати поняття «документування» як похідне від поняття «документ». Саме так до цього питання здебільшого підходять представники не лише юридичних наук, а й інших галузей знань.

При цьому у кожній науці співіснують різні підходи до визначення поняття «документа»: у різних галузях знань між науковцями точаться дискусії з приводу його сутнісних ознак та формулювання дефініції. Дослідження з цього приводу, спеціально проведене А.П. Запотоцьким, дозволило вченому визначити, що документом можна вважати будь-які предмети матеріального світу, придатні для фіксації та передачі у часі і просторі інформації (відомостей) з метою ï збереження та суспільного використання [11, с. 15].

Аналіз цього визначення свідчить, що вчений головне (пріоритетне) змістоутворююче значення надає конкретним предметам матеріального світу, а про інформацію, яка містять документи, згадує лише побіжно, зазначаючи про використання цих предметів 3 метою фіксації інформації (у функціональному контексті). Це не повністю відповідає розумінню сутності документа вченими, які досліджують зміст цього поняття, на міжгалузевому та загальнотеоретичному рівні (так, Л.П. Піддубна головним складником документа вважає саме інформацію, оскільки найрізноманітніші дані, відомості, повідомлення, знання призначені саме для передачі у процесі комунікації [344]).

Але підхід А.П. Запотоцького цілком виправданий з позицій кримінального процесу та повністю відповідає принципу єдності доказів і їх джерел. Саме тому визначення, запропоноване ним ще у 2009 році, що кримінальне процесуальне визначення документа змістовно співпадає з дефініцією, поданою в ст. 99 КПК України, є цілком доречним. Вказана норма визначає документ як спеціально створений з метою збереження інформації. Матеріальний об'єкт містить зафіксовані за допомогою письмових знаків, звуку, зображення тощо відомості, які можуть бути використані як доказ факту чи обставин, що встановлюються під час кримінального провадження [9]. Безумовно, це визначення у запропонованому вигляді не може бути використане для цього дослідження, оскільки воно не охоплює поняття «документа» в оперативно-розшуковій діяльності. Але його доцільно взяти за основу та змінити з урахуванням розуміння документа в теорії ОРД.

Аналіз різноманітних дефініцій документа, запропонованих представниками вказаної науки, дає підстави погодитися 3 підходом М.А. Погорецького. Попередньо вчений виокремив характерні ознаки документа: він є матеріальним об'єктом, що виготовлений (зафіксований) на паперових магнітних, оптичних носіях, перфострічках, перфокартах; він є засобом фіксації і засобом передачі інформації у часі і просторі за допомогою знаків письма та інших технічних засобів відтворення зображення та звуку, мистецьких засобів відтворення дійсності; має певні реквізити та форму; в ньому зафіксовані відомості (фактичні дані, інформація), що має певне значення для його споживача $[12$, с. 223$]$.

Виходячи 3 цього, науковець подав визначення документа ОРД як паперового або іншого матеріального носія, що призначений для зберігання, перетворення, передачі, посвідчення відомостей, на якому у знаковому чи в будь-який іншій спосіб і в певній формі зафіксована оперативно-розшукова інформація, отримана уповноваженими суб'єктами у визначений законом і відомчими нормативними актами спосіб, яка може мати значення для прийняття відповідних рішень в ОРД та інших встановлених законом сферах діяльності [12, с. 225].

Віддаючи належне положенням, розробленим науковцями, зазначу, що вважаю більш раціональним інший підхід, 
який засновується на походженні терміну «документування» від поняття «документ». В цьому контексті документування є створенням або одержанням документів. Цей підхід дозволяє уникнути зайвих дискусій щодо доцільності включення до змісту оперативного документування окремих дій, зокрема систематизації, перевірки та оцінювання фактичних даних.

В умовах дії чинного КПК України сутність документування та його співвідношення з доказуванням досліджував О.О. Подобний. Вчений пов'язує документування винятково 3 проведенням ОРД. Зокрема, він визначає документування як комплекс оперативнорозшукових заходів здебільшого негласного характеру, спрямованих на встановлення фактичних даних про подію злочину й осіб, причетних до його вчинення, перевірку їх достовірності й забезпечення в подальшому можливості використання їх як доказів (у значені ч. 1 ст. 84 Кримінального процесуального кодексу України) у кримінальному провадженні.

На відміну від кримінального процесуального доказування, зазначає вчений, документування в ОРД забезпечує пізнання як обставин, які мали місце в минулому, так і тих явищ, що підготовлюються і відбуваються нині, а також таких, які можуть відбутися в майбутньому. Виходячи із чинного формулювання підстав для проведення ОРД, відповідно до ст. 6 Закону України «Про оперативно-розшукову діяльність», остання набула яскраво вираженого превентивного характеру. Учасники підготовлюваних і таких, що відбуваються, процесів мають можливість безпосередньо спостерігати сам факт злочину, стаючи його очевидцем, внаслідок чого можуть бути допитаними як свідки у кримінальному провадженні.

У цьому випадку безпосереднє спостереження учасниками документування досліджуваної події стає способом пізнання обставин об'єктивної дійсності. Документування забезпечує пізнання досліджуваної події шляхом фіксування фактичних даних, які відбилися в пам'яті потерпілих, очевидців, а також слідів, залишених на предметах та інших матеріальних носіях [13, с. 64-68].

На мою думку, більш обгрунтованим $\epsilon$ підхід П.В. Жовтана та І.О. Сухоради. Вчені дійшли висновку, що документування, здійснюване оперативними підрозділами, має місце як при проведенні ОРД, так і при виконанні ними доручень на проведення негласних слідчих (розшукових) дій. Його результатом $\epsilon$ створення документів, які після відповідної оцінки та перевірки слідчим, прокурором можуть бути використані як докази у кримінальному провадженні. Отже, документування, що здійснюється оперативними підрозділами, є складником забезпечування доказування.

Але воно має й інші завдання, а його результати можуть бути використані в інших сферах діяльності, якщо воно здійснювалося в межах ОРД. Забезпечення доказування оперативними підрозділами не зводиться лише до документування фактичних даних, які в подальшому можуть бути визнані доказами [14]. Аналогічні підходи до визначення співвідношення документування й доказування простежуються й у працях М.Л. Грібова [8].

До викладеного можна додати, що загалом в межах ОРД і кримінального процесу документування потрібно розуміти не лише як діяльність зі створення оперативно-розшукових i кримінальних процесуальних документів, а й як діяльність $з$ одержання вже створених документів, які можуть бути використані для виконання завдань ОРД i кримінального провадження. Адже оперативними працівниками можуть бути одержані вже готові документи, що мають значення для прийняття рішень в ОРД та кримінальному процесі, а також безпосередньо документи, які можуть бути використані як речові докази.

Як слушно зауважує Г.Я. Борисевич, документ є речовим доказом, коли він підпадає під ознаки речових доказів, тобто якщо документ слугував знаряддям злочину, або зберіг на собі сліди злочину, або виявився об'єктом злочинних дій підозрюваного (обвинуваченого) тощо. Якщо документ $€$ речовим доказом, то на нього поширюється процесуальний режим оформлення останнього [15].

Одночасно я не схильний категорично відкидати підхід, запропонований О.О. Подобним [13]. Компроміс між позицією вченого та моїм баченням полягає в тому, щоб досить широке поняття «документування» піддати класифікації на окремі види. При цьому порівняно вузьку категорію «оперативнорозшукове документування» (як таке, що здійснюється винятково в межах ОРД і походить від назви відповідного закону) слід вважати складником оперативного документування (такого, що здійснюється оперативними підрозділами в межах ОРД, так і в межах кримінального процесу й походить від назви ст. 41 КПК України «Оперативні підрозділи» та термінології, яка використовується у ст.ст. 5, 7 Закону України «Про оперативно-розшукову діяльність»).

Складником оперативного документування варто вважати оперативно-технічне 
документування, тобто його різновид, заснований на застосуванні технічних засобів одержання інформації, що не може бути здійснений без їх використання.

Крім того, слід виокремлювати поняття «документування злочинів», яке полягає у створенні та (або) одержанні документів, які містять фактичні дані про кримінально карані діяння окремих осіб та груп. У зв'язку з викладеним слід зауважити, що документування оперативними підрозділами має юридичні, організаційні і тактичні особливості залежно від стадій (етапів), на яких воно проводиться, засобів, які при цьому використовуються, та форм, у яких воно втілюється.

В контексті окресленого спробую виокремити певні етапи документування, які б відрізнялися якісними особливостями, зокрема завданнями, правовідносинами, формою тощо.

Створення оперативно-розшукових документів, які містять фактичні дані про вчинення злочинних дій. Зокрема, це рапорт оперативного працівника про виявлення фактів підготовки або вчинення злочинів. До рапорту можуть бути долучені негласно отримані копії документів, що свідчать про підготовку або вчинення злочинів, звукозапис розвідувального опитування, проведеного оперативним працівником тощо. На цьому етапі дані отримують шляхом оперативного пошуку, який є початковим етапом пізнання в оперативно-розшуковій діяльності [16, с. 129].

Логічним результатом оперативного пошуку за досліджуваним напрямом діяльності є отримання інформації, яка містить підстави, визначені у ст. 6 Закону України «Про оперативно-розшукову діяльність», в разі виявлення яких відповідно до ст. 9 цього закону необхідно заводити оперативно-розшукову справу. В подальшому всі оперативно-розшукові заходи провадять лише в межах цієї справи. Саме там концентруються всі документи, створені оперативними працівниками в процесі розробки.

Наступна стадія документування злочинів співпадає з оперативною розробкою, яку в теорії оперативно-розшукової діяльності, як і оперативний пошук, вважають формою цієї діяльності. В межах оперативної розробки може використовуватися весь арсенал заходів, передбачений у формі прав оперативних підрозділів у ст. 8 Закону України «Про оперативно-розшукову діяльність». Відповідно до вимог ст. 7 Закону України «Про оперативно-розшукову діяльність» після виявлення оперативним підрозділом (в межах провадження по оперативно-розшуковій справі) ознак злочину, необхідно невідкладно направити зібрані матеріали, в яких зафіксовано фактичні дані про протиправні діяння окремих осіб та груп у цій сфері, до відповідного органу досудового розслідування.

Тому третя стадія документування оперативними підрозділами злочинів співпадає із досудовим розслідуванням у кримінальному процесі. На цій стадії оперативні підрозділи керуються положеннями названої статті Закону України «Про оперативнорозшукову діяльність», а також нормами ст. 41 КПК України.

Загалом на кожній стадії документування злочинів необхідно враховувати особливості цієї категорії кримінально-караних діянь. Саме від цих особливостей залежить специфіка організації й тактики заходів, які вживаються оперативними підрозділами.

Наукова новизна публікації полягає в системному аналізі сутності оперативнорозшукового документування в теорії оперативно-розшукової діяльності. Надано характеристику понять «документ», «документування», а також «документування злочинів». У зв'язку з цим виокремлені певні етапи документування, які відрізняються якісними особливостями, зокрема завданнями, правовідносинами, формою. Встановлено, що документування має різні смислові навантаження, які поєднуються в узгодженій діяльності, спрямованій на досягнення мети, виконання завдань або досягнення результату.

\section{Висновки}

У теорії та практиці кримінального процесу та ОРД існує необхідність чітко сформулювати дефініції та визначити співвідношення понять «документування», «документування злочинів», «оперативне документування», «оперативно-розшукове документування», «оперативно-технічне документування» із запровадженням відповідних формулювань у законодавство.

В межах ОРД та кримінального процесу документування потрібно розуміти як діяльність зі створення оперативно-розшукових і кримінальних процесуальних документів, а також діяльність $з$ одержання вже створених документів, які можуть бути використані для виконання завдань ОРД і кримінального провадження.

Документування злочинів полягає у створенні та (або) одержанні документів, які містять фактичні дані про кримінально-карані діяння окремих осіб та груп. Суб'єктами документування злочинів можуть бути оперативні підрозділи, слідчий, прокурор. Воно здійснюється як в межах ОРД, так і в межах кримінального процесу. Документування 
злочинів є основним засобом одержання доказів-документів у кримінальному провадженні.

Оперативне документування (документування, що здійснюється оперативними підрозділами) - діяльність оперативних підрозділів зі створення та (або) одержання документів, які містять інформацію, що може бути використана для прийняття рішень в ОРД, прийняття процесуальних, організаційних і тактичних рішень та доказування у кримінальному провадженні. Оперативнорозшукове документування - різновид оперативного документування, що здійснюється винятково в межах ОРД. Оперативно-технічне документування - різновид оперативного документування, заснований на застосуванні технічних засобів одержання інформації, та який не може бути проведений без їх використання.

Документування злочинів доцільно розмежовувати на окремі стадії, до яких належить оперативний пошук фактичних даних про підготовку та вчинення кримінальних правопорушень, а також осіб, які їх готують і вчиняють; провадження в оперативно-розшукових справах; досудове розслідування.

\section{Список використаних джерел:}

1. Про оперативно-розшукову діяльність : Закон від 18.02.1992 № 2135-XII. Верховна Рада України. URL: http://zakon3.rada.gov.ua/laws/ show/2135-12.

2. Шевчук О.О. Способи скоєння злочинів, пов'язаних із порушенням прав інтелектуальної власності, та особливості їх документування підрозділами ДСБЕЗ МВС України. Митна справа. 2013. № 5 (2.2). C. 63-65.

3. Попов А.П. Актуальні проблеми виявлення та документування правопорушень авторських та суміжних прав, що вчиняються у сфері відтворення та розповсюдження аудіовізуальних творів. Вісник Академії адвокатури України, 2013. Ч. 1. С. $187-193$.

4. Сухорада I.О. Методологія та сучасний стан наукових досліджень документування злочинів у сфері банківського кредитування оперативними підрозділами. Проблеми правознавства та правоохоронної діяльності, 2014. № 4. С. 157-169.

5. Саковський А.А. Особливості документування кримінальних правопорушень, пов'язаних із незаконним обігом наркотичних засобів, психотропних речовин, прекурсорів та їх аналогів. Юридичний часопис Національної академії внутрішніх справ, 2019. № 2 (18). С. 49-59.

6. Біляєв В.О. Актуальні питання тактики документування злочинної діяльності підрозділами карного розшуку при проведенні опитування під час оперативного пошуку. Науковий вісник Дніпропетровського державного університету внутрішніх справ, 2013. № 2. С. 462-469.

7. Погорецький М.А. Теорія доказів - методологічна основа оперативно-розшукового документування організованої злочинної діяльності. Боротьба з організованою злочинністю $і$ корупиією (теорія і практика). 2010. Вип. 22. С. 185-195.

8. Грібов М.Л. Правове регулювання документування вчинення злочину в кримінальному процесі й оперативно-розшуковій діяльності Юридичний часопис Національної академії внутрішніх справ, 2018. № 1 (15). С. 129-140.

9. Кримінальний процесуальний кодекс України : Закон від 13.04.2012 № 4651-VI. Верховна Рада України. URL: http://zakon3.rada.gov.ua/ laws/show/4651-17.

10. Уваров В.Г. Інститут втручання у приватне життя шляхом аудіо-, відеоконтролю. Право $і$ Безпека, 2012. № 5. С. 190-194.

11.Запотоцький А.П. Документи як процесуальні джерела доказів у кримінальному судочинстві : дис. канд. юрид. наук: 12.00.09. Київ, 2009. 233 c.

12. Погорецький М.А. Документ в оперативнорозшуковій діяльності. Міжнародна поліцейська енииклопедія: у 10 т. Відп. редактори: В.В. Коваленко, Є.В. Моісеєв, В.Я. Тацій, Ю.С. Шемшученко. Київ : Атіка, 2010. T. VI: Оперативно-розшукова діяльність поліції (міліції). С. 223-225.

13. Подобний O.O. Співвідношення документування й доказування. Вісник кримінального судочинства, 2015. № 2. С. 64-68.

14. Жовтан П.В., Сухорада I.О. Співвідношення документування та забезпечення доказування в діяльності оперативних підрозділів. Форум права, 2014. № 4. С. 135-141. URL: http:// nbuv.gov.ua/jpdf/FP_index.htm_2014_4_26.pdf.

15. Борисевич Г.Я. Документы как доказательства в российском уголовном процессе. Вестник Пермского университета. URL: www.jurvestnik. psu.ru/ru/vypusk1152012/304.

16. Оперативно-розшукова діяльність : навч. посіб. / Є.М. Моісеєв, О.М. Джужа, Д.Й. Никифорчук та ін.; за ред. проф. О.М. Джужі. Київ : Правова єдність, 2009. 310 с.

Andrii Sakovskyi. The essence of operational and investigative documentation in operational and investigative activities and component of operational and investigative activity

The purpose of the article is to provide the concept and characterize the essence of operational and investigative documentation in operational and investigative activities, as well as to outline the problematic issues regarding its implementation. Scientific methods of analysis, induction and deduction were used in the research process. The theoretical basis of this publication were the works of domestic and foreign scientists on aspects of the activities of pre-trial investigation bodies and criminal police units, as well as consideration of regulations governing their activities. 
The scientific novelty of the publication lies in the systematic analysis of the essence of operational and investigative documentation. The author's definition of "operational and investigative documentation" is given. It is established that the documentation contains a lot of semantic loads, which are combined in a coordinated activity aimed at achieving a goal, accomplishing tasks or achieving a result. It is established that the documentation of operational units has legal, organizational and tactical features depending on the stages at which it is carried out, the means used and the forms in which it is implemented.

In the context of the outlined certain stages of it are distinguished, which differ in tasks, legal relations, form. It is concluded that the documentation of crimes is to create and (or) obtain documents that contain factual data on criminally punishable acts of individuals and groups.

The subjects of documenting crimes can be operational units, investigators, prosecutors. It is carried out both within the operational and investigative activities, and within the criminal process. Documenting crimes is the main means of obtaining evidence-documents in criminal proceedings.

Operational documentation (documentation carried out by operational units) the activities of operational units to create and (or) obtain documents that contain information that can be used for decision-making in operational and investigative activities, procedural, organizational and tactical decisions and evidence in criminal proceedings.

Operational and investigative documentation - a type of operational documentation, which is carried out exclusively within the operational and investigative activities. Operational and technical documentation a type of operational documentation based on the use of technical means of obtaining information and can not be carried out without their use.

Key words: operative-search activity, documentation, operative-search documentation, documentation of commission of a crime, criminal police. 